Acta vet. scand. $1970,11,37--48$.

From the Department of Clinical Biochemistry and the Department of Surgery, Royal Veterinary College, Stockholm, Sweden.

\title{
ELIMINATION OF HOMOLOGOUS AND HETEROLOGOUS (BOVINE) SERUM ALBUMIN FROM THE BLOOD CIRCULATION IN THE $D\left(G^{*}\right)$
}

By

L. Ekman, G. Nilsson and G. Tufvesson

Several authors have shown that bovine serum albumin can be used as a plasma expander in the dog (Davis \& Eaton 1942, Harthoorn 1953, Turner 1963, Elffors \& Tufvesson 1966). It has particularly been tried in haemorrhagic shock but also in other conditions with disturbed fluid balance. Negative effects which would render the use of bovine albumin riskful or dubious for this species have not become known (Tufvesson 1967). It can therefore be anticipated that it will gain more and more extensive use.

The distribution and metabolism of radio-labelled autologous, homologous and heterologous albumin in the dog have been reported in several investigations (e.g. Takeda 1964, Wetterfors 1965). However, remarkably enough, studies on the metabolism of bovine serum albumin in the dog seem not to have been reported in the literature. Considering the clinical use of bovine serum albumin in canine medicine it seems desirable to elucidate this. The present investigation was carried out in order to investigate the elimination rate of intravenously administered bovine serum albumin in normal dogs and in dogs which have been deprived of considerable blood volumes. The investigation was

*) The investigation was carried out with financial support from AB Astra, Södertälje, Sweden. 
carried out by use of radioactive $\left(\mathrm{I}^{131}\right)$ bovine serum albumin. As a reference also the elimination of homologous serum albumin was studied. The canine albumin was labelled with $\mathbf{I}^{125}$. Thus each dog received simultaneously $\mathrm{I}^{131}$ - and $\mathbf{I}^{125}$-labelled albumin.

\section{MATERIAL AND METHODS}

The experiments were carried out with ten healthy full-grown dogs of both sexes. The age did not exceed two years. The dogs were in a normal nutritional state and their weight varied from 9.2 to $18.0 \mathrm{~kg}$ with a mean weight of $13.7 \mathrm{~kg}$. All the dogs were fed by commercial dog food and had free access to drinking water which was mixed up with $1 \mathrm{~g} \mathrm{KI} / \mathrm{l}$. The dogs received iodinized water approximately one week before start of the experiment and then during the whole experimental period.

\section{Normal dogs}

Five dogs received by intravenous injection $4.0 \mathrm{ml}$ of a solution containing $24.5 \mu \mathrm{Ci} \mathbf{I}^{131}$-labelled bovine serum albumin (3 $\mathrm{mg}$ albumin) and $51.5 \% \mathrm{Ci} \mathrm{I}^{125}$-labelled canine serum albumin (5 mg albumin). From a different vein blood samples were obtained after 5, 10, 15, 20 and 30 min. as well as 1, 2, 3, 4, 6 and 12 hrs. Subsequently one sample was taken daily. Two dogs were studied for 14 days while two dogs were sacrificed after eight days. From these two dogs samples were taken from different organs and tissues for determination of $\mathrm{I}^{131}$ and $\mathrm{I}^{125}$.

\section{Bled dogs}

In five of the dogs a polyethylene catheter with an inner diameter of $1.77 \mathrm{~mm}$ was introduced in the femoral artery. The catheter was used for bleeding of the dogs and for subsequent administration of bovine serum albumin. Introduction of catheter, bleeding and administration of bovine albumin were carried out with the dogs in moderate thiopentone sodium narcosis with endotracheal intubation. The dogs were bled in the mean by $33 \%$ of the calculated total blood volume which was assumed to represent $9.5 \%$ of their body weight. Thereafter bovine serum albumin was given intra-arterially as a $20 \%$ solution (Alboven ${ }^{\circledR}$ ) in a volume of $10 \mathrm{ml}$ per $100 \mathrm{ml}$ of removed blood. This corresponds to approximately $0.6 \mathrm{~g}$ albumin $/ \mathrm{kg}$ body weight. Immediately afterwards $I^{131}$-labelled bovine serum albumin and $I^{125}$-labelled 
canine serum albamin were injected intra-arterially in the same amounts as those reported earlier for the non-bled dogs. Blood samples were then taken from another vessel (cephalic antebrachial vein) at intervals which have been stated for the non-bled dogs. The concentration of $\mathrm{I}^{125}$ and $\mathrm{I}^{131}$ in plasma was followed for 14 days in one dog. Four dogs were studied during eight days and were thereafter sacrificed by intravenous administration of sodium mebumal. Tissue samples and organs (Table 2) were obtained for assessment of radioactivity.

Bovine serum albumin (Alboven $\AA$ ) as well as homologous canine serum albumin were supplied by AS Astra (Södertälje, Sweden). According to information by the supplier these two albumin preparations were produced by identical means, mainly according to Cohn's fractioning method. They were supplied as $20 \%$ albumin solutions in $0.9 \%$ saline. Examination by discelectrophoresis has shown that the canine albumin contained further four protein components. The bovine albumin contained five components in addition to albumin (Brummerstedt-Hansen 1967). In this connection may be mentioned that another commercially available bovine serum albumin "Bovine Albumin Powder, Fraction V from Bovine Plasma” (Armour Pharmaceutical Company, USA) when assessed with the same investigational technique proved to contain seven protein components in addition to albumin (Brummerstedt-Hansen).

Labelling of the bovine serum albumin with $I^{131}$ as well as of the canine serum albumin with $I^{125}$ was carried out by $A B$ Atomenergi, Nyköping, according to the method described by McFarlane (1958). Sterilization was carried out by pressure filtration. Sterility and pyrogenicity tests were carried out in accordance with the requirements of the Swedish Pharmacopoiea. The amount of free $I^{131}$ and $I^{125}$ in the labelled albumin solutions were in all determinations less than $1 \%$ when assessed after precipitation of the proteins with sodium wolframate. At delivery the bovine serum albumin contained $10.4 \mathrm{mCi}^{\mathrm{I}^{131}} / \mathrm{g}$ albumin. The corresponding value for the canine serum albumin was $\mathbf{1 0 . 3}$ $\mathrm{mCi} \mathrm{I}^{125} / \mathrm{g}$ albumin.

Assessment of radioactivity was carried out in $1.0 \mathrm{ml}$ blood plasma in a well-scintillation detector which was coupled to a Nuclear Date 512 channel gamma spectrometer. In these determinations only 127 channels were used and each channel corresponded to $0.067 \mathrm{MeV}$. $\mathrm{I}^{125}$ was measured in channels $0-13$ and 


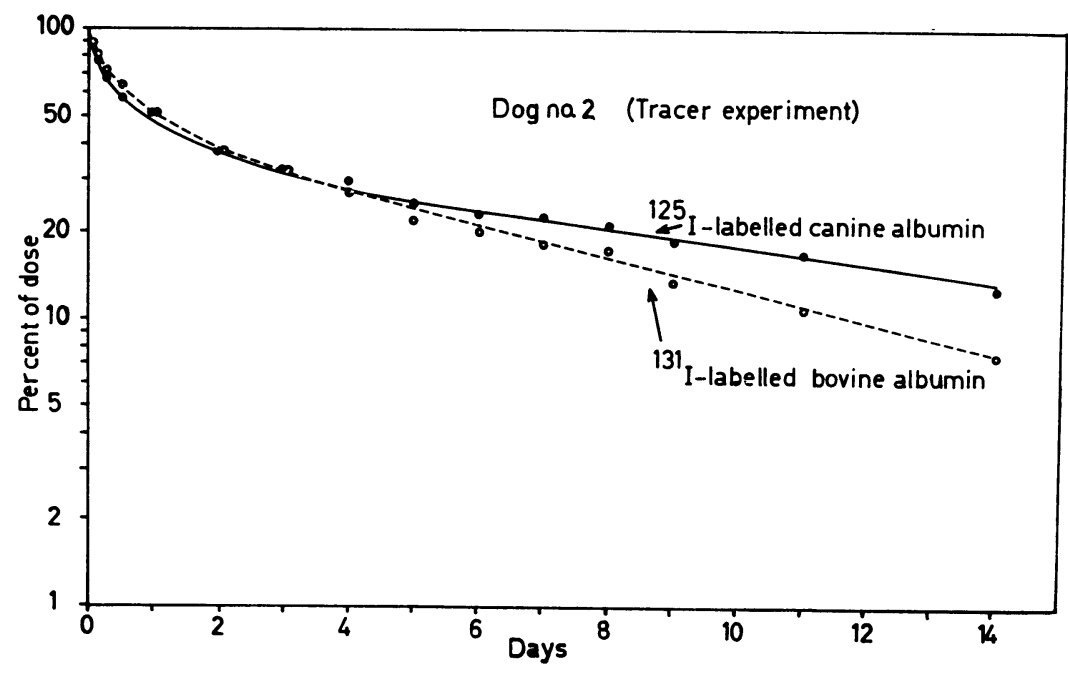

Figure 1. Elimination of homologous and heterologous serum albumin in the control dog.

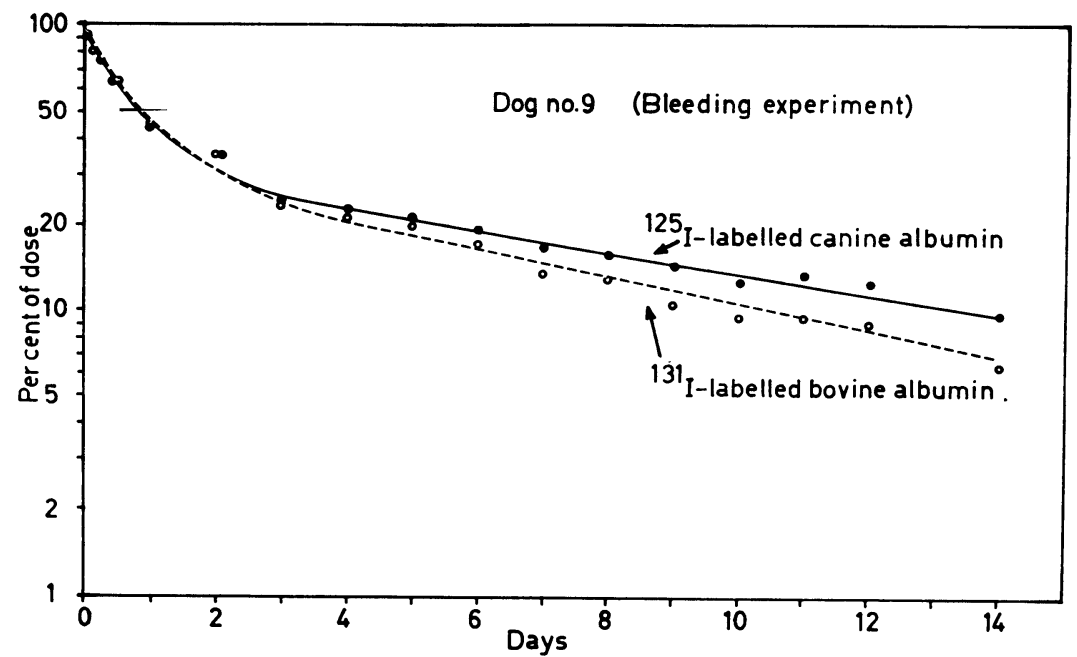

Figur e 2. Elimination of homologous and heterologous serum albumin in a dog which was bled by $33 \%$ of the calculated blood volume. Treated with $10 \mathrm{ml}$ Alboven $® / 100 \mathrm{ml}$ blood loss. 
T a b l e 1. Data of the dogs and half-life period for labelled homologous and heterologous serum albumin.

\begin{tabular}{|c|c|c|c|c|c|c|c|c|}
\hline & \multirow{2}{*}{$\begin{array}{l}\text { Dog } \\
\text { no. }\end{array}$} & \multirow{2}{*}{$\begin{array}{c}\text { Weight } \\
\text { kg }\end{array}$} & \multicolumn{2}{|c|}{ Plasma volume } & \multirow{2}{*}{$\begin{array}{l}\text { Serum } \\
\text { albumin } \\
\mathrm{g} / \mathbf{1 0 0 \mathrm { ml }}\end{array}$} & \multirow{2}{*}{$\begin{array}{l}\text { Circulating } \\
\text { albumin } \\
\text { g/kg body } \\
\text { weight }\end{array}$} & \multicolumn{2}{|c|}{ Half-life (days) } \\
\hline & & & ml & $\mathrm{ml} / \mathrm{kg}$ & & & $\begin{array}{l}\text { canine } \\
\text { albumin }\end{array}$ & $\begin{array}{l}\text { bovine } \\
\text { albumin }\end{array}$ \\
\hline \multirow{5}{*}{$\begin{array}{l}0 \\
0 \\
0 \\
0 \\
0 \\
0 \\
0 \\
\\
0 \\
0 \\
0\end{array}$} & 1 & 9.8 & 496 & 50.6 & 3.3 & 1.67 & 5.5 & 4.8 \\
\hline & 2 & 9.2 & 482 & 52.3 & 3.6 & 1.88 & 6.2 & 4.8 \\
\hline & 3 & 12.5 & 673 & 53.8 & 2.2 & 1.19 & 6.5 & 5.2 \\
\hline & 4 & 12.8 & 673 & 52.6 & 2.6 & 1.37 & 6.0 & 4.7 \\
\hline & 5 & 19.5 & 1009 & 51.7 & 4.1 & 2.12 & 7.0 & 5.4 \\
\hline \multirow{7}{*}{ 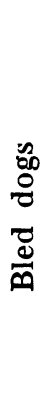 } & & & & & & & \multicolumn{2}{|c|}{$\begin{array}{c}6.24 \pm 1.49 \quad 4.98 \pm 0.30 \\
t=4.176\end{array}$} \\
\hline & 6 & 17.5 & 741 & 42.3 & $\left.3.5^{\star}\right)$ & & 6.5 & 4.7 \\
\hline & 7 & 12.5 & 516 & 41.3 & 4.1 & & 5.8 & 4.6 \\
\hline & 8 & 14.0 & 605 & 43.2 & 4.0 & & 6.5 & 4.6 \\
\hline & 9 & 18.0 & 765 & 42.5 & 2.7 & & 6.0 & 5.5 \\
\hline & 10 & 11.5 & 522 & 45.4 & 4.7 & & 7.2 & 4.5 \\
\hline & & & & & & & $\begin{array}{r}6.40 \pm 0.55 \\
t=\end{array}$ & $\begin{array}{l}4.78 \pm 0.41 \\
491\end{array}$ \\
\hline
\end{tabular}

*) Before bleeding of the dog.

$I^{131}$ in channels 45-64. By assessment of standard solutions for the actual isotope the correction factor for the $I^{131}$ addition to $\mathrm{I}^{125}$ could be calculated. Approximately $1 \mathrm{~g}$ of tissue samples were measured directly in the same way as plasma samples, however, using corrections for geometric deviations.

\section{RESULTS}

Typical elimination curves for the labelled canine and bovine serum albumins from normal control dogs as well as bled dogs are shown in Figs. 1 and 2 . During the four to five days subsequent to the injection the course of the curves is almost identical. Thereafter the shape of the curve can be described as a simple exponential function. The biological half-lives for this slow phase are evident from Table 1 . In all animals the labelled bovine serum albumin is eliminated more rapidly than the labelled canine serum albumin. It is also evident that the half-lives for control and bled dogs are not statistically different. Accordingly more labelled canine albumin will be found intravascularly after the 


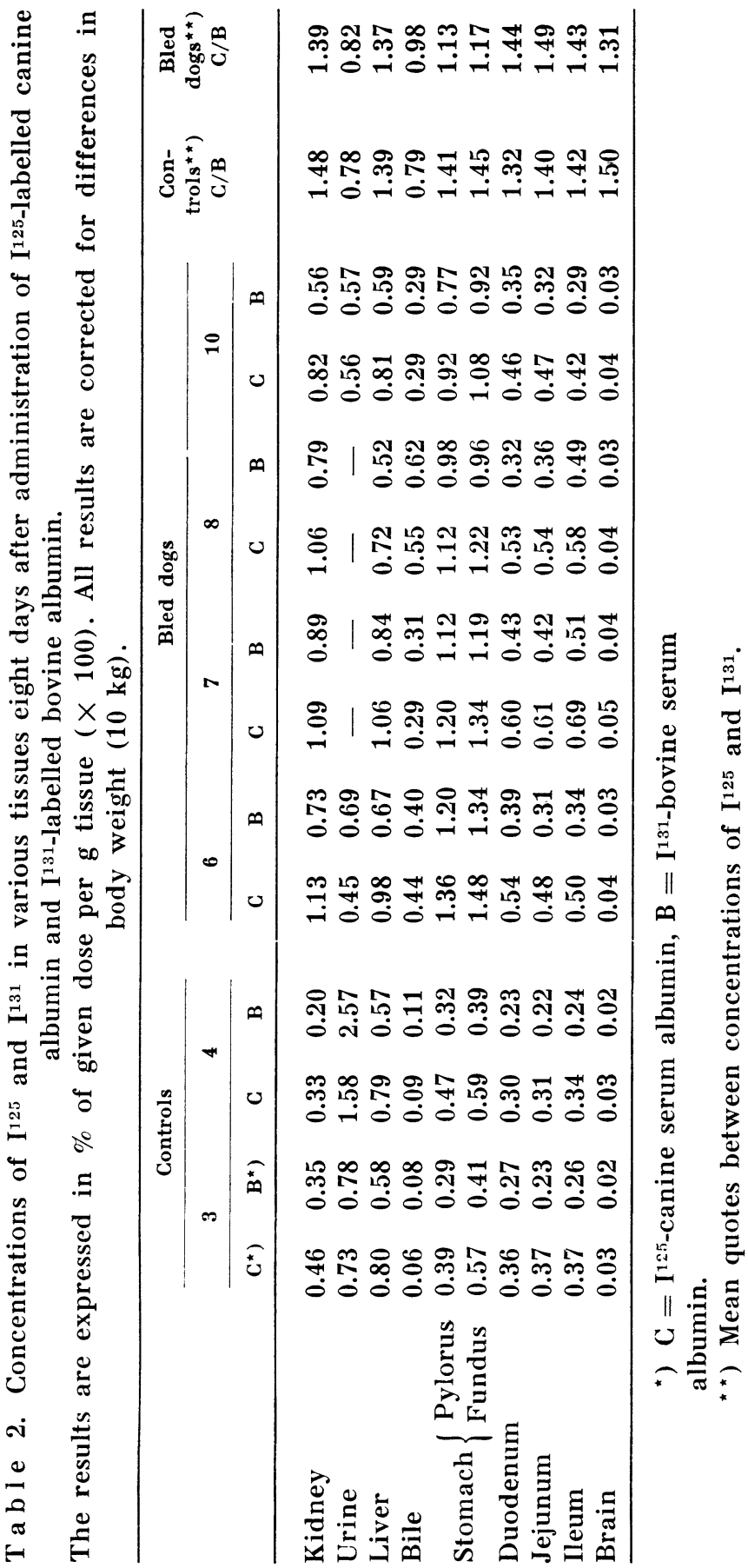


reported time. No differences can be found between control and bled dogs. In the control dogs (five animals) $37.9 \pm 3.9(\vec{x} \pm s$ ) and $26.4 \pm 5.1 \%$ of the given amount of labelled canine and bovine albumin respectively remained intravascularly. The corresponding values for the bled dogs were $35.3 \pm 3.8$ and $27.7 \pm 2.7 \%$ respectively. Significant differences between control and bled dogs were not found neither for canine nor bovine serum albumin.

The distribution of $\mathrm{I}^{125}$ and $\mathrm{I}^{131}$ in different tissues eight days after administration of $I^{125}$ labelled canine serum albumin and $I^{131}$ labelled bovine serum albumin may be seen from Table 2. Urinary and bilary concentrations have been included. The samples have been collected from the urinary bladder or the gall bladder in connection with sampling from different tissues. As is evident concentrations of $\mathrm{I}^{131}$ (bovine serum albumin) are in excess of those of $\mathrm{I}^{125}$ (canine serum albumin) in both urine and bile. In all other tissues the concentrations of $I^{125}$ exceed those of $I^{131}$.

Because of the small number of animals included in the investigation a statistical evaluation has not been carried out. However, it is evident that the concentration is obviously lower in the brain than in any other of the investigated tissues. Of particular interest is a comparison of the quote between $\mathrm{I}^{125}$ and $I^{131}$ in different tissues. As is evident from Table 2 this quote is comparatively constant, approximately 1.4, in all examined tissues in both the control and the bled dogs. An exception is the quote in the stomach wall of the bled dogs where it amounts to $\mathbf{1 . 1 5}$.

\section{DISCUSSION}

No type of anaphylactic reaction connected with the intravenous administration of homologous or heterologous serum albumin has been observed in the present investigation. Neither was such a reaction expected on the basis of the results obtained in earlier experiments with bovine serum albumin in dog (Elffors \& Tufvesson 1966).

In this investigation the radioactive labelling of the albumin preparations has been carried out by the method described by McFarlane (1958). It has been shown, conclusively, that serum albumin labelled with radioiodine by means of this method behaves in the organism identically with native albumin (Bennhold 
\& Kallee 1959, Freeman et al. 1959). There is also clear evidence available that radioiodine which has been liberated during the catabolism of labelled serum albumin is not utilized for resynthesis of albumin or other proteins (Cohen et al. 1956, Zizza et al. 1959 ). $\mathrm{I}^{125}$ - and/or $\mathrm{I}^{131}$-labelling of serum albumin thus is a very suitable method for the study of the albumin turnover, presupposed that denaturation of the albumin preparations can be avoided during the labelling process. In the present investigation the urine was quantitatively collected during four days in two dogs (nos. 2 and 9). During the first 24 hrs. less than $9 \%$ of the total dose of given canine or bovine serum albumin was recovered. This indicates that the labelled albumin preparations which have been used have not been denaturated (Wetterfors 1965 ).

Graphical analysis of the elimination curves for $\mathrm{I}^{125}$ canine albumin and $I^{131}$ bovine albumin in plasma indicates that these can be best described as a 3-exponential equation. It has been stated by Takeda (1964) and it is also evident from Figs. 1 and 2 in this investigation that it is necessary to follow the curves for plasma activity during at least 14 days in order to be able to give an exact mathematical definition of the curves. In the present investigation six of the dogs have been sacrificed after eight days for examination of the tissue distribution of the albumin preparations. It has not been attempted to define the equations for the different elimination curves. However, the biological half-lives for the slowest components in the curves have been calculated. Half-lives for homologous serum albumin in both control dogs and bled dogs were about the same, $6.2 \pm 1.5$ and $6.4 \pm 0.6$ days. Wasserman \& Mayerson (1951) arrived at corresponding values of 5.5 days while longer half-life has been reported by Wetterfors (1965) 7.0-9.0 days, Deichmiller et al. (1953) 8.3 days and particularly Takeda 11.2 days. This variation may be explained by differences in the labelled homologous albumin preparations but also by differences in the length of the observation period. A shorter observation period tends to give shorter half-lives for the exponential part of the plasma activity curves. As previously stated an observation period of eight days is somewhat too short for an absolutely correct determination of the half-life period. However, the object of this investigation was mainly to compare the elimination of homologous serum albumin to that of bovine serum albumin, and for this 
type of investigation the observation period is assumed to be satisfactory, in particular when it is considered that the investigation was carried out as a double-tracer experiment where each dog was his own control.

From the investigation is evident that half of the given albumin is eliminated within one day and $2 / 3$ have left the circulation in three days. The curves furthermore show that the elimination of the homologous albumin takes place at the same rate as that of the heterologous albumin during the first four to five days. From a practical clinical point of view this is a significant information as it shows that bovine serum albumin can be regarded to be a plasma expander in dog equivalent to homologous serum albumin. However, from the fifth day after administration of the albumin the heterologous albumin seems to disappear more rapidly from the circulation. The half-lives for the slow exponential phase in the control dogs and in the bled dogs were 5.0 and 4.8 days respectively. These values are in good agreement with corresponding values obtained for horse serum albumin in the dog by Patterson et al. (1963), who reported 4.9-5.2 days. For human serum albumin Wetterfors (1965) reports a value of 4.8 days. If it is assumed that the slow phase in the elimination curve is representative for the catabolic rate of labelled serum albumin (Cohen et al.) it would seem that this would be similar for heterologous serum albumins from man, horse and cattle. The higher concentrations of $I^{125}$ in bile and particularly in urine (Table 2) must be interpreted as an indication for the more rapid catabolism of the heterologous albumin in dog.

A statistically significant difference between elimination rates of the heterologous albumin in control dogs and bled dogs has not been found. Usually the elimination of serum albumin increases in connection with operative interventions, depending on a temporary loss of albumin to the wound oedema (Mouridsen 1967). The insignificant intervention necessary for introduction of the catheter in the femoral artery did not cause a postoperative oedema to a degree which might influence the circulating albumin.

The concentration of homologous and heterologous serum albumin in different tissues is reported in Table 2. A calculation of the distribution of albumin in the intra- and extracellular tissues has not been carried out. It should, however, be noted 
that the quote between homologous and heterologous serum albumin is comparatively constant in all examined tissues. Neither exists a difference between control dogs and bled dogs, with the exception of the quote for the stomach wall. This is considerably lower in the bled dogs and this can be interpreted as an indication for increased excretion of heterologous serum albumin via the stomach wall (Wetterfors 1964).

\section{REFERENCES}

Bennhold, $H$. \& E. Kallee: Comparative studies on the half-life of $I^{131}$ labelled albumins and non-radioactive albumins in a case of analbuminaemia. J. clin. Invest. 1959, 38, 863-872.

Brummerstedt-Hansen, E.: Unders $\varnothing$ gelser af præparatet Albuven med anvendelse af immun- og disc-electroforese. (Investigation of the preparation Alboven by means of immun- and disc-electrophoresis). Report to AB Astra, Södertälje 1967.

Cohen, S., R. C. Holloway, C. M. Matthews \& A. S. McFarlane: Distribution and elimination of ${ }^{131} \mathrm{I}$ and ${ }^{14} \mathrm{C}$-labelled plasma proteins in the rabbit. Biochem. J. 1956, 62, 143-154.

Davis, H. A. \& A. G. Eaton: Intravenous administration of bovine serum albumin as a blood substitute in experimental secondary shock. Proc. Soc. exp. Biol. (N. Y.) 1942, 49, 20-22.

Deichmiller, M. P., I. F. Dixon \& P. H. Maurer: Half-life homologous serum albumin in several species. Fed. Proc. 1953, 12, 386.

Elffors, S. \& G. Tufvesson: Heterologous albumin (bovine) as a plasma expander in the dog. Cornell Vet. 1966, 56, 104-123.

Freeman, T., C. M. Matthews, A. S. McFarlane, H. Bennhold \& E. Kallee: Albumin labelled with iodine-131 in an analbuminaemic subject. Nature (Lond.) 1959, 183, 606.

Harthoorn, A. M.: The effect of various forms of fluid replacement during circulatory imbalance in the dog. Parts I, II and III. Vet. Rec. 1953, 65, 35-74.

McFarlane, A. S.: Efficient tracer-labelling of plasma proteins. Nature (Lond.) 1958, 183, 53.

Mouridsen, $H$. T.: Turnover of human serum albumin before and after operations. Clin. Sci. 1967, 33, 345-354.

Patterson, R., W. W. Y. Chang, J. J. Pruzansky \& G. L. Portney: The immunologic response of dogs to soluble protein antigens. J. Immunol. 1963, 91, 129-135.

Takeda, Y.: Metabolism and distribution of autologous and homologous albumin-I ${ }^{131}$ in the dog. Amer. J. Physiol. 1964, 206, 1227-1228.

Tufvesson, G.: Bovint serumalbumin som plasmaexpander på hund. (Bovine albumin as plasma expander in the dog). Nord. Vet.Med. 1967, 19, 62-70. 
Turner, T.: Shock and first aid in the dog and cat. J. small Anim. Pract. 1963, 4, 299-302.

Wasserman, K. \& H. S. Mayerson: Exchange of albumin between plasma and lymph. Amer. J. Physiol. 1951, 165, 15-26.

Wetterfors, J.: The normal passage of serum-albumin into the gastrointestinal tract and its role in the catabolism of albumin. An experimental study in the dog. Acta med. scand. 1964, 176, 787-799.

Wetterfors, J.: Catabolism and distribution of serum-albumin in the dog. An experimental study with homologous ${ }^{131}$ I-albumin. Acta med. scand. 1969, 177, 243-256.

Zizza, F., T. J. Campbell \& E. B. Reeve: The nature and rates of excretion of radioactive breakdown products of $I^{131}$-albumin in the rabbit. J. gen. Physiol. 1959, 43, 397-401.

\section{SUMMARY}

The elimination of intravenously administered I ${ }^{131}$-labelled bovine serum albumin has been compared to the elimination rate of $\mathrm{I}^{125}$ labelled homologous serum albumin in normal and bled dogs, which had lost considerable blood volumes. The investigation shows that during the first four to five days after the administration the elimination is similar of heterologous and homologous serum albumin. This proves that bovine serum albumin can be regarded to be an equivalent plasma expander to homologous serum albumin in the dog. Elimination of homologous as well as heterologous serum albumin follows a simple exponential curve during four to five days after administration. The intravascular half-lives for homologous serum albumin were $6.4 \pm 1.5$ days and $6.4 \pm 0.6$ days respectively in control and bled dogs. Corresponding values for heterologous (bovine) serum albumin were $5.0 \pm 0.3$ and $4.8 \pm 0.4$ days respectively.

The quote for cencentrations of homologous and heterologous serum albumin in different tissues was found to be relatively constant approximately 1.4. An exception was the stomach wall in bled dogs which had a quote of 1.1 only.

\section{SAMMANFATTNING \\ Elimination av homologt och heterologt (bovint) serumalbumin från blodbanorna hos hund.}

En undersökning har företagits för att klarlägga eliminationshastigheten av intravenöst tillfört I $^{131}$-märkt bovint serumalbumin jämfört med eliminationen av I $^{125}$-märkt homologt serumalbumin dels hos normala och dels hos hundar, som tappats på betydande blodmängder. Undersökningen visar att eliminationen av heterologt och homologt serumalbumin är densamma under de första 4-5 dagarna efter tillförseln. Detta visar att bovint serumalbumin kan uppfattas som likvärdigt med homologt serumalbumin som plasmaexpander hos hund. Eliminationen för såväl homologt som heterologt serumalbumin 
följer ett enkelt exponentiellt förlopp 4-5 dagar efter tilförseln. Halveringstiden intravaskulärt för homologt serumalbumin var $6,4 \pm 1,5$ dagar och 6,4 $\pm 0,6$ dagar hos kontrollhundar och blödda hundar. Motsvarande värden för det heterologa (bovina) serumalbuminet var $5,0 \pm 0,3$ och $4,8 \pm 0,4$ dagar.

Kvoten för koncentrationen av homologt och heterologt serumalbumin i olika vävnader befanns vara relativt konstant omkring 1,4. Undantag utgjorde magsäcksväggen hos blödda hundar där kvoten var endast 1,1 .

Received April 29, 1969). 